(Jurnal Kajian Kebijakan dan Ilmu Administrasi Negara)

\title{
Penerapan Finger Print Dalam Perspektif Manajemen Aparatur Sipil Negara di Dinas Pertanian Kabupaten Minahasa
}

Meis M. Hatidja a, ${ }^{\text {** }}$, Fitri H.Mamonto ${ }^{\mathrm{b}, 2}$, A. R. Dilapanga ${ }^{\mathrm{c}, 3}$

${ }^{a}$ Universitas Negeri Manado, Pascasarjana Universitas Negeri Manado, Tomohon Indonesia

1meishatidja2017@gmail.com*; yombog@yahoo.com; abdulrahmandilapanga@unima.ac.id

INFO ARTIKEL

Diterima 00 April 00

Disetujui00 Oktober 00

Key Word

Finger Print,

Management,

State Civil Apparatus

A B S T R A C T (TIMES NEW ROMAN; 10)

This study aims to describe how the Finger Print Application in

the Perspective of State Civil Apparatus Management in the Agriculture Office of Southeast Minahasa Regency using qualitative research methods. The research indicators used were the use of finger print in terms of knowledge, the views of the state civil servants about finger print, the availability of supporting facilities, use of Finger Print in terms of discipline and providing Additional Income based on Finger print. The results showed that the application of finger print as a controlling function of changes in attitudes and behavior of the State Civil Apparatus became more diligent, obedient to the rules and responsible at work as well as providing convenience in evaluating attendance reports quickly and accurately. with the application of finger print employees will try to arrive on time in the morning at 08.00 Wita, afternoon break 12.00-13.00 and afternoon at 16.15 WIB so that it shows an increase in discipline and an increase in employee productivity. with the application of finger print it avoids the occurrence of fraud and reduces fictitious spending funds in providing additional income for employees because it is paid according to the print out results of employee attendance which are recorded directly online

\section{INTISARI INTISARI}

\section{Kata kunci:}

Sidik Jari

Manajemen

Aparatur Sipil Negara
Penelitian ini bertujuan menggambarkan bagaimana Penerapan Finger Print dalam Perspektif Managemen Aparatur Sipil Negara di Dinas Pertanian Kabupaten Minahasa Tenggara dengan menggunakan metode penelitian kualitatif. Indikator penelitian yang digunakan yaitu Penggunaan Finger Print 
dalam hal Pengetahuan, Pandangan Aparatur Sipil Negara tentang finger print,Ketersediaan Sarana Pendukung, pemanfaatan Finger Print dalam hal disiplin dan pemberian Tambahan Penghasilan berdasarkan Finger print. Hasil Penelitian menunjukkan dengan penerapan finger print sebagai fungsi controlling terjadinya perubahan sikap dan prilaku Aparatur Sipil Negara menjadi lebih rajin, taat pada aturan dan bertanggung jawab dalam pekerjaan serta memberikan kemudahan dalam mengevaluasi laporan kehadiran secara cepat dan tepat. dengan penerapan finger print pegawai akan berusaha datang tepat waktu pagi pukul 08.00 Wita, siang istirahat 12.00-13.00 dan sore pukul 16.15 wita sehingga menunjukkan adanya peningkatan disiplin dan meningkatnya produktivitas pegawai. dengan penerapan finger print menghindarkan terjadinya kecurangan dan menekan dana pengeluaran fiktif dalam pemberian tambahan penghasilan bagi pegawai karena dibayarkan sesuai dengan hasil print out kehadiran pegawai yang terekam langsung secara online

\section{Copyright $\odot 2020$ (Meis Hatidja).All Right Reserved}

\section{Pendahuluan}

Dalam era globalisasi yang sedang dan sementara berlangsung ini peran sumber daya manusia semakin penting dalam mewujudkan organisasi yang kompetitif dalam bidang pekerjaan dan tanggung jawabnya sehingga

mampu memberikan nilai tambah bagi organisasi atau perusahaan. Berdasarkan Peraturan Presiden Nomor 81/2010 Grand Desain Reformasi Birokrasi 2010-2025, tunjangan kinerja diberikan kepada Aparatur Sipil Negara di Kementerian dan lembaga yang telah melaksanakan reformasi birokrasi jika

kualitasnya membaik diberikan peningkatan, jika kualitasnya buruk maka diberikan penurunan.

Layaknya seorang pegawai disuatu perusahaan maka Aparatu r Sipil Negara selain mendapatkan gaji juga mendapatkan tunjangan kinerja daerah yang pemberiannya diatur dengan Peraturan Pemerintah yang dijadikan salah satu dasar dalam pemberian tambahan pegawai. seiring dengan perkembangan zaman, ilmu pengetahuan dan teknologi memunculkan sebuah terobosan baru dengan penggunaan mesin absensi sidik jari atau finger print sebagai upaya untuk mengetahui keberadaan pegawai dan sebagai fungsi controlling/pengawasan bagi aparatur sipil negara. Sistem absensi finger print tersebut dapat mencatat kehadiran pegawai sehingga dengan ketepatan waktu dalam bekerja menghasilkan disiplin dan meningkatkan kualitas kerja.

Di Tahun 2016 Pemerintah Kabupaten Minahasa Tenggara menerapkan sistem absensi sidik jari atau finger print dalam rangka memperbaiki managemen sumber daya aparatur sipil negara dengan harapan adanya peningkatan disiplin dan kinerja pegawai sehingga didalamnya tercipta manajemen aparatur sipil negara yang baik. Dengan dikeluarkannya aturan oleh pemerintah dengan menerapkan sistem absensi finger print bagi aparatur sipil negara di Kabupaten Minahasa Tenggara selain sebagai fungsi controlling itu juga dijadikan salah satu dasar dasar dalam memberikan tambahan penghasilan yang dibayarkan.

Perubahan dari absen manual dengan sidik jari atau finger print dilakukan dengan tujuan untuk meningkatkan disiplin, kinerja dan terciptanya manajemen aparatur sipil negara yang baik menuju good governance. Banyak nilai positif dari penggunaan finger print untuk absensi namun kadang disalahgunakan oleh aparatur sipil negara hanya untuk tujuan supaya tambahan penghasilannya tidak terpotong tidak disertai dengan kinerja yang baik.

Dari permasalahan di atas maka peneliti tertarik untuk meneliti terkait Penerapan finger print 
dalam

perspektif manajemen aparatur sipil negara di Dinas Pertanian Kabupaten Minahasa Tenggara.

\section{Rumusan Masalah}

Dari latar belakang diatas, kemudian peneliti merumuskan masalah Bagaimana Penerapan Finger Print dalam perspektif manajemen Aparatur Sipil Negara di Dinas Pertanian Kabupaten Minahasa Tenggara yang bertujuan menggambarkan juga bagaimana penerapan finger print yang diterapkan bagi aparatur sipil negara di Dinas pertanian Kabupaten Minahasa Tenggara/.

\section{Metode Penelitian}

Penelitian ini adalah penelitian kualitatif dengan metode pengambilan data melalui wawancara, observasi dan dokumentasi dengan fokus penelitian pada indikator ${ }^{1}$ )Penerapan Finger Print (Pengetahuan, Pandangan ASN, ketersediaan sarana pendukung), $\left.{ }^{2}\right)$ Pemanfaatan finger print (disiplin), ${ }^{3}$ )Pemberian Tambahan Penghasilan berdasarkan finger print. Data dianalisis melalui pengumpulan data, penyajian data, reduksi data dan penarikan kesimpulan. Komponenkomponen analisis data tersebut diatas oleh Miles dan Huberman

(Sugiyono 2013) digambarkan sebagai berikut

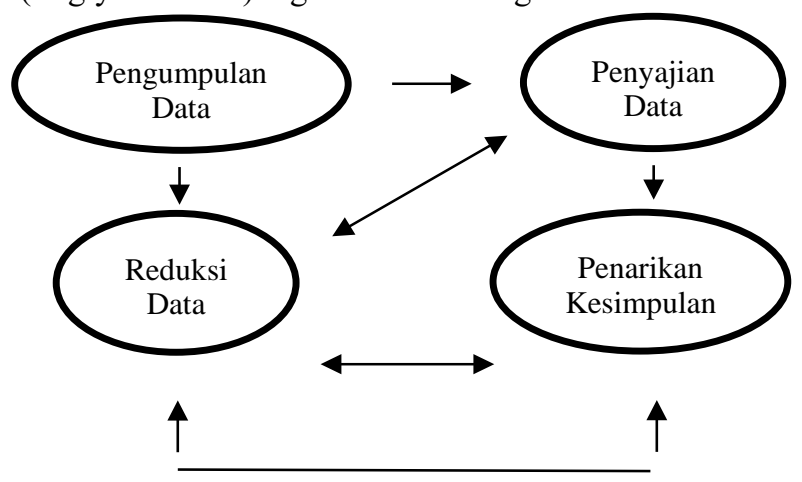

\section{Hasil dan Pembahasan}

[1] 1. Penggunaan Finger Print (Pengetahuan, Pandangan ASN dan Ketersediaan Sarana Pendukung)

Di Tahun 2016 Pemerintah Kabupaten Minahasa Tenggara mulai menerapkan sistem absensi sidik jari atau finger print bagi aparatur sipil negara dalam rangka memperbaiki managemen sumber daya aparatur sipil negara dengan harapan adanya peningkatan kualitas sumber daya manusia yang berdisiplin dan berkualitas.

Dari hasil penelitian menunjukkan dengan adanya inovasi diterapkannya sistem absensi sidik jari atau finger print maka terlihat perubahan sikap pegawai. Pegawai akan berusaha datang lebih awal pagi sebelum jam 08.00 Wita da

n pulang setelah jam kerja berakhir pukul 16.15 Wita. Hal ini memberikan kemudahan dalam fungsi pengawasan atau controlling setiap kehadiran pegawai, tidak ada rekayasa data kehadiran. Karena data sidik jari setiap pegawai sudah terekam dengan mesin finger print yang terhubung secara online maka secara otomatis data absensi setiap aparatur sispil negara tersimpan di database mesin absensi sehingga menghasilkan laporan catatan yang akurat dan tepat mulai jam tiba, jam istirahat dan jam pulang.

Dengann Ketersediaan sarana pendukung disetiap BPP 12 Kecamatan

masing-masing terdapat satu unit mesin finger print memudahkan juga dalam mengontrol kehadiran penyuluh di 12

Kecamatan. Dari data hasil penelitian ini juga menunjukkan selang tiga bulan September Oktober November rata rata presentase kehadiran meningkat sehingga finger print merubah pola pikir dan mainset aparatur sipil negara di Dinas Pertanian Kabupaten Minahasa Tenggara untuk ada dalam perubahan yang dulunya malas menjadi lebih memperhatikan waktu sehingga terciptanya manajemen aparatur sipil negara yang baik.

\section{Pemanfaatan Finger Print Terkait}

\section{[2] Disiplin}

Berdasarkan hasil penelitian dengan pemanfaatan finger print di Dinas pertanian Kabupaten Minahasa Tenggara menjadikan aparatur sipil negara menjadi lebih rajin, taat pada aturan dan kreatif dalam bekerja menghasilkan sumber daya yang berkualitas. Karena terikat dengan finger print pegawai akan berusaha datang tepat waktu pagi jam 08.00 wita dilanjutkan dengan apel pagi, istirahat siang jam 12.00-13.00 wita dan sore 16.15 Wita. Dengan datang tepat waktu aparatur sipil negara sudah lebih bijak dalam menghargai waktu untuk bekerja sehingga secara otomatis akan memiliki lebih banyak waktu untuk menyelesaikan pekerjaan maka terjadinya peningkatan produktivitas kerja pegawai termasuk di dalamnya kemampuan pegawai untuk melaksanakan tugas pokok dan fungsi (tupoksi).

Sedamaryanti (2016:317)

dalambukunyamenyebutkanbahwaproduktivitas kerja pegawai merupakan salah satu dari pemberdayaan sumber daya manusia yang mempunyai tujuan dan korelasi yang sangat singnifikan terhadap organisasi.

Dalam aturan sudah di atur untuk jam finger print pagi 08.00 Wita, s iang waktu istirahat harus dua kali finger print keluar istirahat dan masuk istirahat dengan rentang waktu untuk finger print pukul 12.0013.00, sore pukul 16.15. Dari waktu tersebut yang sudah diseting dalam mesin finger print maka satu menit saja pun terlewati dari jam yang diatur maka dianggap pegawai tersebut sudah terlambat yang nantinya akan diperhitungkan dalam pemberian tambahan penghasilan pemotongan sebesar 5\%. Data juga menunjukkan menurunnya presentase pegawai yang Terlambat Datang (TD) dalam sebulan. Hal ini dilihat dari selang tiga bulan terakhir sejak penelitian ini (Agustus, September, Oktober) yang dalam sebulan 2122 hari kerja pegawai yang hanya satu sampai dua kali saja terlambat Datang (TD) demikian juga halnya dengan pulang cepat (PC). 
Empat

kali finger print dalam sehari terutama juga untuk finger print siang bagi pegawai struktural maupun penyuluh apabila melaksanakan kunjungan ataupun pendampingan maka harus membuat surat ijin keluar kantor yang ditandatangani oleh Kepala Dinas sebagai bukti kehadiran.

Selain melakukan finger print juga disertai dengan tersedianya absen manual yang harus diisi dan ditandatangani oleh pegawai dengan tujuan memberikan kemudahan dan sebagai pengingat bagi pegawai untuk melengkapi dokumen pendukung seperti surat tugas ataupun surat isin keluar yang disesuaikan dengan hari dan tanggal ketika tidak melakukan finger print.

Dari hasil penelitian dengan pemanfaatan finger print dijumpai dengan pada saat melakukan finger print yang sudah injuri time waktunya, kadang sidik jari tidak langsung terbaca oleh mesin muncul tanda X (warna merah) yang menandakan sidik belum berhasil sehingga pegawai harus harus mengulangnya kembali sampai terbaca oleh mesin muncul tanda $\sqrt{ }$ (warna hijau) pertanda sidik berhasil.

\section{Pemberian Tambahan Penghasilan}

\section{[3] Pegawai Berdasarkan Finger Print}

Di Kabupaten Minahasa Tenggara telah dikeluarkan peraturan tentang tata cara pemberian Tambahan Penghasilan Pegawai dan finger print yang dijadikan sebagai salah satu dasar dalam pemberian tambahan penghasilan pegawai. Dari hasil penelitian dengan penerpana finger print membantu untuk tidak terjadinya manipulasi data kehadiran ataupun kecurangan sehingga tambahan penghasilan yang diterima setiap pegawai dibayarkan sesuai dengan kehadirannya. Penerapan finger print bisa menekan dana pengeluaran fiktif karena perhitungan tambahan penghasilan pegawai dihitung melalui kehadiran pegawai yang diperolehnya lewat data yang terekam pada mesin finger print sehingga tambahan penghasilan pegawai dibayarkan sesuai dengan hasil print out rekapan kehadiran maka dana atau budget yang dikeluarkan memang sesuai dengan kehadiran pegawai yang terekam lewat mesin absensi sidik jari.

Dalam permintaan dana untuk tambahan penghasilan pegawai apabila ketidakhadiran pegawai di kantor yang berupa izin, sakit, izin keluar harus disertai dengan bukti sebagai dokumen pendukung yang diperhitungkan dalam pemberian tambahan penghasilan. Apabila melewati jam atau waktu yang telah diatur dalam figer print maka konsekuensinya pemotongan tambahan penghasilan yang terlambat pemotongan $5 \%$, tidak finger print jam keluar istirahat 3\%, masuk istirahat 3\%, dan pulang cepat $4 \%$.

Menurut Sedamaryanti (2016:389) bahwa salah satu hak PNS adalah memperoleh tunjangan dan gaji yang adil dan layak sesuai dengan beban kerja dan tanggung jawab.

Dari hasil penelitian ini ditemuinya ketidakpuasan pegawai terkait dengan presentasi untuk pemotongan 3\% apabila tidak melaksanakan tugas dikantor karena alasan sakit. Munculnya juga ketidakpuasan pegawai dengan besarnya tambahan penghasilan untuk pegawai eselon III, IV, Staf dan penyuluh dengan beban kerja dan pemanfaatan finger print yang diharuskan sampai empat kali dalam sehari.

\section{Kesimpulan}

Berdasarkan analisis hasil penelitian dan pembahasan maka ditarik kesimpulan bahwa :

.1. Dengan penerapan finger print sebagai fungsi controlling maka terjadinya perubahan sikap dan prilaku. Aparatur Sipil Negara menjadi lebih rajin, taat dan bertanggung jawab dalam pekerjaan serta memberikan kemudahan dalam mengevaluasi laporan kehadiran secara cepat dan tepat. .

2. Dengan penerapan finger print pegawai akan berusaha datang tepat waktu pagi pukul $08.00 \mathrm{Wita}$, siang istirahat 12.0013 .00 dan sore pukul 16.15 wita sehingga menunjukkan adanya peningkatan disiplin dan meningkatnya produktivitas pegawai

3.Dengan penerapan finger print menghindarkan terjadinya kecurangan dan menekan dana pengeluaran fiktif dalam pemberian tambahan penghasilan sehingga dana atau budget dibayarkan sesuai dengan hasil print out kehadiran pegawai yang terekam langsung secara online dalam mesin absensi tersebut.

4. Dengan penerapan finger print sebagai fungsi controlling yang memberikan kemudahan dalam mencatat kehadiran menjadikan aparatur sipil negara yang berdisiplin, jujur, rajin dan memiliki produktivitas kerja yang tinggi untuk terwujudnya manajemen aparatur sipil negara yang baik menuju pada good governance.

\section{[4] Referensi}

[5] Andri Feriyanto. dkk.2015. Pengantar Manajemen (3 in 1). Media Tera.Yokyakarta

[6] Deddy Mulyadi. dkk. 2016. Administrasi Publik untuk Pelayanan Publik. Alfabeta Bandung

[7] Dwiyanto, Agus. 2005. Mewujudkan Good Governance Melalui Pelayanan Publik. Yogyakarta: Gajah Mada University Press

[8] Emma Maeyasari. Pengaruh Efektivitas Penerapan Absensi Finger Print

[9] Edy Sutrisno. 2011.Manajemen Sumber daya Manusia. Kencana Prenada media group.

[10] Evi Masengi.2018.Pengantar Manajemen Pelayanan Publik. Wineka Media.Malang

[11] Hasibuan. 1994. Manajemen Sumber Daya Manusia Dasar dan Kunci Keberhasilan. Jakarta PT Midas Surya Gravindo

[12] Peraturan Bupati Nomor 60 Tahun 2016 tentang Tugas Pokok dan Fungsi Dinas Pertanian Kabupaten Minahasa Tenggara 
[13] Prawirosentono, Suryadi.1999.Kebijakan

Kinerja Karyawan.BPFE.Yokyakarta

[14] Radminto,2005.ManajemenPelayanan.Yogyak arta

[15] Rivai,Vethzal \& Basri.2005.Performance Appraisal:Sistem yang tepat untuk Menilai Kinerja Karyawan dan Meningkatkan Daya Saing Perusahaan.Jakarta. PT. Raja Grafindo Persada

[16] Santoso,Pandji.2008.Administrasi Publikteori dan aplikasi good governance. Bandung. Refika Aditama

[17] Sedarmayanti,2016 Manajemen Sumber Daya Manusia,Reformasi Birokrasi dan Manajemen Pegawai Negeri Sipil. Bandung. Refika Aditama

[18] Sugiyono.2013 Metode Penelitian Pendekatan Kuantitatif,KualitatifdanR\&D.Bandung.Alfabe ta

[19] T.Hani Handoko. 2001. Manajemen Edisi 2. BPFE.Yogyakarta 